\title{
ZOOGEOMORFOLOGIA: INFLUÊNCIAS DA FAUNA NA EVOLUÇÃO E DINÂMICA DOS SISTEMAS GEOMORFOLOGICOS
}

\author{
Roberto Marques Neto \\ Professor do Departamento de Geociências e do Programa de Pós-graduação em Geografia da Universidade \\ Federal de Juiz de Fora - UFJF \\ roberto.marques@ufjf.edu.br
}

\begin{abstract}
Resumo
O enfoque zoogeomorfológico se estabelece a partir do papel dos animais como agentes geomórficos, e, embora perfaça uma importante interface entre a Geomorfologia e a Biogeografia, são raros os estudos pautados na referida abordagem no escopo da cultura geomorfológica brasileira. A falta de estudos em zoogeomorfologia e a premissa de que animais, vertebrados e invertebrados, influenciam na dinâmica e evolução de sistemas geomorfológicos, se inscrevendo explicitamente nos fluxos de matéria e energia, foram os elementos motivadores deste trabalho, cujo objetivo é discutir de forma sistemática os animais como agentes geomórficos, propondo uma classificação de tais ações a partir de sua manifestação escalar, expressão espacial e efeitos na estrutura superficial da paisagem mediante uma abordagem sistêmica. A discussão aqui apresentada foca enfaticamente os vertebrados, atentando de forma mais detalhada para a mastofauna, classe considerada como a de maior influência nos processos de superfície, para a qual foi constatada importância significativa e que varia em modalidade (pisoteio, escavação, chafurdação, etc.) e intensidade conforme diferentes táxons e distintos contextos bioclimáticos.
\end{abstract}

Palavras-chave: Animais como agentes geomórficos. Pisoteio. Escavação. Estrutura da paisagem.

\section{ZOOGEOMORPHOLOGY: THE ROLE OF WILDLIFE IN THE EVOLUTION AND DYNAMICS OF GEOMORPHOLOCICAL SYSTEMS}

\begin{abstract}
The zoogeomorphological approach is established by the role of animals as geomorphic agents and although it makes an important interface between Geomorphology and Biogeography studies based on the referred approach in the scope of the Brazilian geomorphological culture are rare. The lack of studies in zoogeomorphology and the premise that animals, vertebrates and invertebrates, have influence in the dynamics and evolution of geomorphological systems explicitly inscribing itselves in the flows of matter and energy were the motivating elements of this work which aims on discussing systematically the animals as geomorphic agents proposing a classification of such actions from its scalar manifestation, spatial expression and effects on the superficial structure of the landscape through a system approach. The discussion presented here focus emphatically on the vertebrates, attempting in a more detailed way to the mastofauna which is considered to be the one with the greatest influence on the surface processes for which was found significant importance and that varies in modality (trampling, digging, wallowing etc) and intensity according to different taxons and distinct bioclimatic contexts.
\end{abstract}

Keywords: Animals as geomorphic agents. Trampling. Excavation. Landscape structure.

\section{INTRODUÇÃO}

Malgrado o papel importante exercido pela fauna na dinâmica superficial e na evolução das vertentes, as pesquisas que integram geomorfologia e biogeografia são incipientes no Brasil, ainda que alguns estudos de caso tenham atinado a estas interessantes interfaces. Nessa seara, Thomaz e Dias

$\begin{array}{llllll}\text { Caminhos de Geografia } & \text { Uberlândia } & \text { v. 20, n. } 72 & \text { Dez/2019 } & \text { p. 275-293 Página } 275\end{array}$


bibliográficas, interpretações em campo e enquadramento metodológico ancorado na abordagem geossistêmica. Assume-se o intuito, a este respeito, de se estabelecer uma proposição unificada entre grupos taxonômicos, as diferentes ações geomórficas por eles exercidas e suas respectivas escalas de manifestação.

\section{ESCOPO METODOLÓGICO}

O interesse classificatório aqui externado partiu da proposição de uma chave de classificação dos fatos geomórficos associados à fauna (Figura 1), estabelecida a partir de lógicas escalares e espaciais interpretadas com base no reconhecimento da existência do geossistema em consonância aos postulados estabelecidos por Sochava $(1971,1977,1978)$, ampliados por Isachenko (1973) e difundidos por vasto rol de geógrafos eslavos e do leste europeu até os tempos atuais.

As ações geomórficas exercidas pela fauna em seus aspectos gerais foram classificadas, conforme a figura 1, a partir de três critérios: (A) abrangência espacial, em referência ao nível escalar de manifestação (local, regional e suprarregional); (B) manifestação na paisagem (superficial, subsuperficial, subaquoso); (C) expressão espacial (pontual, linear, areolar). A partir desses critérios é possível compor classificações para as referidas ações geomórficas sempre que as correlações se fizerem coerentes e correspondentes com a realidade. Alguns exemplos elencados abaixo indicam associações possíveis, entre outras tantas:

(A) Ações locais de manifestação superficial e expressão pontual;

(B) Ações locais de manifestação superficial e expressão linear;

(C) Ações locais de manifestação subsuperficial e expressão pontual;

(D) Ações locais de manifestação subsuperficial e expressão linear;

(E) Ações regionais de manifestação superficial e expressão areolar.

Figura 1 - Classificação de ações geomórficas exercidas pela fauna e suas relações com o geossistema.

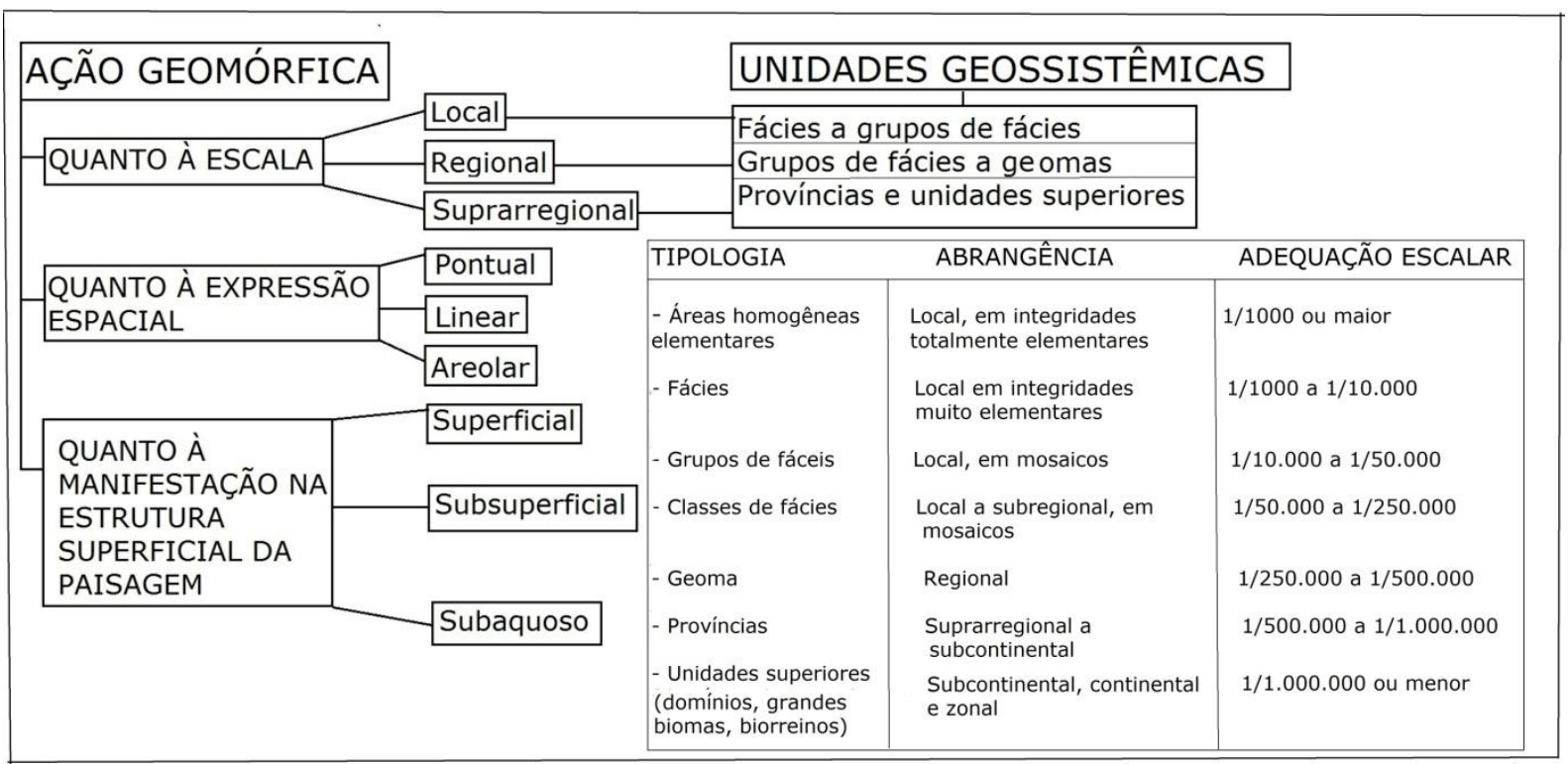

Algumas ações geomórficas assumem mais de uma característica, podendo desenvolver feições geomorfológicas de manifestação ao mesmo tempo pontual e linear, por exemplo. Ainda, quanto à abrangência espacial, um grupo considerável de ações geomórficas pode se apresentar, ao mesmo

\begin{tabular}{lllll}
\hline Caminhos de Geografia & Uberlândia & v. 20, n. 72 & Dez/2019 & p. 275-293 Página 277
\end{tabular}


tempo, em níveis hierárquicos locais e regionais, e até mesmo suprarregionais, sugerindo, inclusive, uma flexibilidade na definição da hierarquia dos geossistemas. Outras delas podem ter manifestação estanque em cada uma das três categorias.

No esquema aqui proposto, as escalas de manifestações das ações geomórficas da fauna, das formas geradas e dos processos correlatos foram associadas aos seus respectivos níveis hierárquicos dos geossistemas em conformidade ao estabelecido por Sochava (1978), procurando relacionar de forma mais estreita o papel da fauna no estado dinâmico do geossistema e na própria estrutura da paisagem. O esquema classificatório que o autor propõe discerne as integridades homogêneas (geômeros) e heterogêneas (geócoros), sendo os geômeros correspondentes aos tipos de paisagem e os geócoros aos indivíduos geográficos. Partindo dessa construção bilateral, optou-se por dialogar diretamente com as tipologias (geômeros) em função do caráter universal dessas integridades espaciais, o que, para fins de aplicações práticas em estudos de caso, permite uma relação direta entre a ação geomórfica do organismo e o tipo de paisagem no qual ela opera.

Por estas premissas têm-se que ações geomórficas de abrangência local são aquelas cuja interpretação se faz viável a partir do estudo das fácies físico-geográficas, unidades formadas pela interpenetração de áreas homogêneas elementares, ao passo que aquelas cuja espacialidade se estabelece em níveis hierárquicos regionais são relacionadas aos grupos, classes de fácies e geomas, podendo ainda haver desdobramentos suprarregionais no que se refere às relações entre a fauna e os processos de superfície. Cabe salientar que, no escopo da presente abordagem, o que se chama de níveis regionais tem significado físico-territorial correspondente a uma ordem de grandeza geossistêmica, e não se liga propriamente ao conceito de região e aos estudos regionais levados a efeito pelos geógrafos humanistas. Nesse sentido, o arranjo de diferentes grupos e classes de fácies de manifestação sub-regional consubstancia um nível hierárquico superior (geomas), que marca a passagem das grandezas locais para as regionais. Sochava (1978) frisa ainda que é o macrogeócoro, correspondente do geoma na fileira dos geócoros, a integridade espacial que melhor define a paisagem, sendo considerado pelo autor como sinônimo de Landschaft.

Doravante, os aspectos inerentes às ações geomórficas são discutidos em consonância aos diferentes grupos taxonômicos e aos fatos geomórficos associados a tais ações. O mérito taxonômico se pautou em algumas premissas, a saber: (1) animais partilham da estrutura e dinâmica da paisagem e são agentes geomórficos efetivos, com ações variadas no que tange à geração de formas e deflagração de processos de superfície; (2) a classe dos mamíferos é aquela de maior valor zoogeomorfológico entre os vertebrados; (3) a geração de formas e processos similares pode se dar em diferentes táxons em função de evolução convergente. $O$ universo da presente exposição se generaliza nos organismos Cordatha segundo suas três classes majoritariamente terrestres (Reptilia, Ave e Mammalia), excluindo-se a classe Amphibia em função de sua importância geomorfológica mais restrita em comparação às demais, conforme já ressaltado por Butler (1995). A exposição seguiu a sequência evolutiva clássica - repteis, aves e mamíferos, apenas como critério para a organização estrutural do texto, considerando o fato de repteis e aves partilharem do mesmo grupo monofilético. Os mamíferos, dada sua importância de vulto no tocante à geração de morfologias e processos superficiais e subsuperficiais, foram discutidos em caráter mais detalhado, diferenciandose seus trabalhos geomórficos a partir das ordens mais consensualmente consideradas.

\section{ANIMAIS COMO AGENTES GEOMÓRFICOS: DIFERENCIAÇÃO E CLASSIFICAÇÃO}

Os esforços de interpretação e organização sistemática dos efeitos impressos pela fauna na paisagem, enfaticamente aqueles de cunho geomorfológico, são bastante restritos, ainda que Butler (1985) tenha apresentado uma subdivisão sucinta, porém abrangente, das atividades geomórficas dos animais, incluindo os invertebrados de forma genérica e todas as classes de mamíferos. Aproveitando essa sistematização prévia, foram inseridos outros fatos geomórficos aqui

$\begin{array}{llllll}\text { Caminhos de Geografia } & \text { Uberlândia } & \text { v. 20, n. } 72 & \text { Dez/2019 } & \text { p. 275-293 } & \text { Página } 278\end{array}$


considerados, agregando ainda o papel da fauna domesticada e a expressão espacial destes agrupamentos.

O quadro 1 apresenta os principais fatos geomórficos produzidos por repteis, diferenciados segundo sua escala de abrangência, seu estrato de manifestação na estrutura superficial da paisagem (superficial/subsuperficial/subaquoso) e sua expressão espacial (pontual/linear/areolar).

Quadro 1 - Classificação dos fatos geomórficos produzidos por repteis.

\begin{tabular}{|c|c|c|c|c|c|}
\hline AÇÃO & ESCALA & MANIFESTAÇÃO & $\begin{array}{l}\text { EXPRESSÃO } \\
\text { ESPACIAL }\end{array}$ & $\begin{array}{l}\text { PRINCIPAIS } \\
\text { AGENTES }\end{array}$ & $\begin{array}{l}\text { FATOS } \\
\text { GEOMÓRFICOS }\end{array}$ \\
\hline Rastejo & Local & Superficial & Linear & Grandes Chelonia & $\begin{array}{c}\text { Formação de sulcos } \\
\text { e erosão linear }\end{array}$ \\
\hline Litofagia & Local & Superficial & Pontual & Crocodilomorfos & $\begin{array}{l}\text { Desagregação de } \\
\text { rochas e erosão }\end{array}$ \\
\hline Escavação & Local & $\begin{array}{l}\text { Subsuperficial a } \\
\text { subaquoso }\end{array}$ & Pontual & $\begin{array}{l}\text { Cobras, lagartos, } \\
\text { iguanas, } \\
\text { crocodilomorfos }\end{array}$ & $\begin{array}{l}\text { Desagregação da } \\
\text { cobertura superficial } \\
\text { e erosão; formação } \\
\text { de pequenas } \\
\text { depressões }\end{array}$ \\
\hline Nidificação & Local & $\begin{array}{ll}\text { Superficial } & \text { e } \\
\text { subsuperficial } & \end{array}$ & Pontual & $\begin{array}{l}\text { Crocodilomorfos, } \\
\text { quelônios e } \\
\text { outros repteis }\end{array}$ & $\begin{array}{c}\text { Escavação de } \\
\text { buracos, edificação } \\
\text { de montes com } \\
\text { interferências nos } \\
\text { processos erosivos } \\
\text { e sedimentares }\end{array}$ \\
\hline Chafurdação & Local & Superficial & Pontual & Crocodilomorfos & $\begin{array}{l}\text { Formação de } \\
\text { pequenas } \\
\text { depressões. }\end{array}$ \\
\hline Pisoteio & Local & Superficial & $\begin{array}{l}\text { Linear e } \\
\text { areolar }\end{array}$ & $\begin{array}{l}\text { Aligatores em } \\
\text { migração e outros } \\
\text { crocodilomorfos }\end{array}$ & $\begin{array}{l}\text { Sulcamento linear } \\
\text { da superfície e } \\
\text { erosão marginal. }\end{array}$ \\
\hline
\end{tabular}

Fica notório que a expressão espacial da zoogeomorfologia ligada aos repteis é eminentemente local. Mesmo as migrações de grandes crocodilomorfos, embora seguramente interferentes nos processos erosivos e deposicionais fluviais, não definem propriamente uma expressão na paisagem regional que a valha tal enquadramento, como o será em outros casos adiante discutidos. As ações geomórficas afetam fundamentalmente os estratos superiores da paisagem, e que correspondem ao horizonte A dos solos ou camadas mais emergentes das coberturas sedimentares, ainda que atividades de escavação impliquem no acesso a níveis mais profundos da estrutura superficial da paisagem, com incisões nas coberturas de alteração que variam de centímetros a metros. Em alguns casos, a transformação se dá em ambiente aquoso, no caso de repteis aquáticos que escavam tocas nos diques marginais, algumas abaixo do nível d'água, e em outros casos na passagem dos níveis aéreos para os subaquosos. Crocodilos são capazes de escavar tocas de até dez metros de comprimento, por vezes habitadas até o desmoronamento.

As ações geomórficas de repteis, além de majoritariamente locais, tem uma expressão pontual bem marcada na escala da paisagem, definidas nos pontos de escavação, chafurdação e assim por diante. As tipicidades lineares e areolares são aquelas causadas por deslocamento, tanto o rastejo

$\begin{array}{llllll}\text { Caminhos de Geografia } & \text { Uberlândia } & \text { v. 20, n. } 72 & \text { Dez/2019 } & \text { p. 275-293 } & \text { Página } 279\end{array}$


como o pisoteio. Grandes quelônios em movimento direcional bem definido costumam deixar pequenos sulcos e estrias pronunciadamente lineares ao longo de sua rota, normalmente feições transitórias que rapidamente são apagadas pelos processos de superfície. Estas rotas lineares são bem marcadas pelo descolamento de diversas espécies de tartarugas marinhas que nidificam nas planícies costeiras, e que abrem caminho frente aos sedimentos do prisma praial deixando na retaguarda descontinuidades bem marcadas na acomodação sedimentar. O pisoteio, por seu turno, tem caráter um pouco mais difuso, definindo pequenas áreas de focos erosivos e trilhas, como aqueles verificados nas migrações de grandes aligátores apontadas por Butler (1995).

No Brasil, grandes concentrações de jacarés (Caiman latirostris), fundamentalmente na região do Pantanal (MT e MS), implicam em remobilização permanente dos sedimentos lacustres e flúviolacustres que margeiam os corpos d'água desse grande conjunto de planícies inundáveis, o que ocorre até mesmo em situações de baixa concentração de indivíduos. De fato, a prevalência dos repteis nas margens das lagoas e nas suas adjacências, onde sua passagem é recorrente, desencadeia tais processos e gera microformas flagrantemente vinculadas a esta ação (Figura 2).

Figura 2 - Evidência de ação geomórfica levada a efeito por Caiman latirostris em ambiente de sedimentação lacustre (Aquidauana, MS).

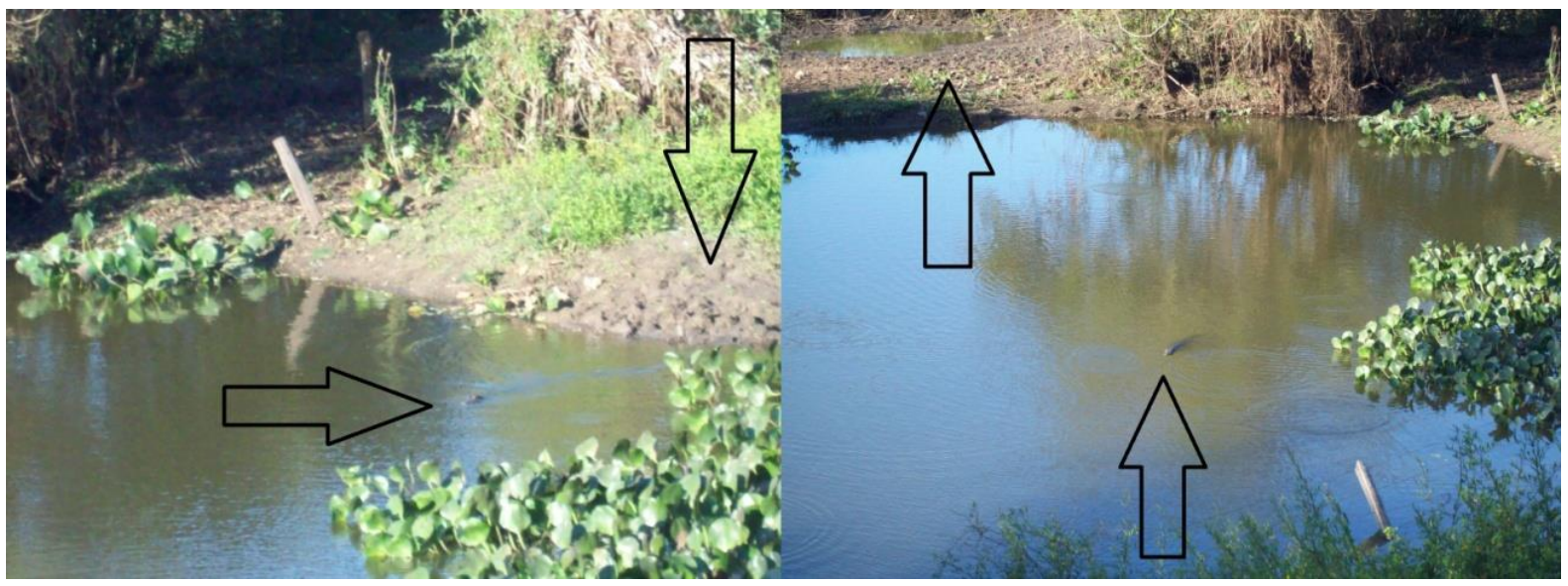

O registro supraexposto flagrou a ação de remobilização de sedimentos lacustres através do pisoteio, gerando pequenas sucessões de montículos e microdepressões pontuando bolsões de materiais ainda mais incoesos. Pelo exposto, nota-se que jacarés afetam geoambientes relativamente homogêneos que formam conjuntos de áreas homogêneas mais elementares dadas por superfícies sedimentares com vegetação ausente a rarefeita, mas também fácies com vegetação rasteira mais contínua de gramíneas e hemicriptófitos. Por área homogênea elementar entende-se uma extensão da superfície terrestre caracterizada por mesmo relevo (em seus aspectos morfológicos e de declividade), mesma base geológica sob um sistema de transformação pedológica contíguo em seus aspectos físico-químicos, subjacentes a um mesmo tipo vegetacional ou forma de uso da terra (SOCHAVA, 1978; CAVALCANTI, 2013). Ainda, é importante notar que, na região do Pantanal, sua ação geomórfica se concentra em um determinado estado dinâmico da paisagem, que vige durante o período de vazante, quando o nível de água das lagoas fica baixo ao ponto de deixar as margens expostas. É nessa época do ano que algum processo erosivo avulta, tendo nos jacarés um agente geomórfico efetivo, incrementando input energético para remobilização e fluxo de detritos em uma região de declive baixíssimo e fundamentalmente deposicional.

Para a classe das aves, uma sumarização dos fatos geomórficos associados ao táxon é apresentada no quadro 2, abaixo. Notoriamente, os processos geomórficos vinculados à ação das aves também

$\begin{array}{llllll}\text { Caminhos de Geografia } & \text { Uberlândia } & \text { v. 20, n. } 72 & \text { Dez/2019 } & \text { p. 275-293 } & \text { Página } 280\end{array}$


se desenvolvem em escala local, afetando fácies físico-geográficas, muitas vezes com efeitos contundentes na estrutura superficial da paisagem. No entanto, malgrado esta dominância de efeitos em níveis escalares locais, aves coloniais podem ser determinantes nas transformações morfopedológicas vigentes em sua área de influência.

Quadro 2 - Classificação dos fatos geomórficos produzidos por aves.

\begin{tabular}{|c|c|c|c|c|c|}
\hline AÇÃO & ESCALA & MANIFESTAÇÃO & $\begin{array}{l}\text { EXPRESSÃO } \\
\text { ESPACIAL }\end{array}$ & $\begin{array}{l}\text { PRINCIPAIS } \\
\text { AGENTES }\end{array}$ & FATOS GEOMÓRFICOS \\
\hline Geofagia & Local & Superficial & Pontual & Vários & $\begin{array}{l}\text { Remobilização da camada } \\
\text { superficial do manto de } \\
\text { intemperismo } \\
\text { favorecimento } \\
\text { processos erosivos }\end{array}$ \\
\hline $\begin{array}{l}\text { Transporte de } \\
\text { material } \\
\text { clástico }\end{array}$ & Local & Superficial & Pontual & $\begin{array}{l}\text { Corvídeos, narcejas } \\
\text { e outros grupos que } \\
\text { se alimentam de } \\
\text { frutos de casca } \\
\text { rígida ou animais } \\
\text { com carapaça }\end{array}$ & 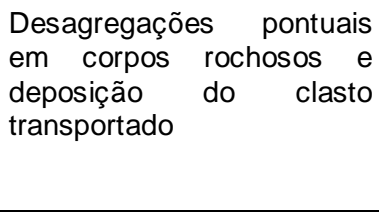 \\
\hline $\begin{array}{l}\text { Transporte de } \\
\text { material para } \\
\text { construção de } \\
\text { ninho }\end{array}$ & Local & Superficial & Pontual & Vários & $\begin{array}{l}\text { Remoção e transporte de } \\
\text { seixos, serrapilheira e } \\
\text { vegetação }\end{array}$ \\
\hline Raspagem & Local & Superficial & Pontual & Vários & $\begin{array}{l}\text { Desagregação e remoção } \\
\text { de } \\
\text { intemperizadas e formação } \\
\text { de montículos }\end{array}$ \\
\hline $\begin{array}{l}\text { Formação de } \\
\text { colônias }\end{array}$ & Local & Superficial & Areolar & $\begin{array}{lll}\text { Vários, } & & \text { com } \\
\text { destaque } & & \text { para } \\
\text { pinguins } & \text { e } & \text { aves } \\
\text { marinhas } & & \end{array}$ & $\begin{array}{l}\text { Enriquecimento de guano, } \\
\text { formação de solos ou } \\
\text { horizontes orgânicos, } \\
\text { desagregação e remoção } \\
\text { de fragmentos de rocha e } \\
\text { coberturas intemperizadas }\end{array}$ \\
\hline $\begin{array}{l}\text { Pisoteio } \\
\text { sulcamento }\end{array}$ & Local & Superficial & Pontual & Vários & $\begin{array}{l}\text { Desagregação e remoção } \\
\text { de fragmentos de rocha e } \\
\text { coberturas intemperizadas }\end{array}$ \\
\hline $\begin{array}{l}\text { Escavação e } \\
\text { construção de } \\
\text { tocas }\end{array}$ & Local & $\begin{array}{l}\text { Superficial a } \\
\text { subsuperficial }\end{array}$ & Pontual & Vários & $\begin{array}{l}\text { Desagregação e remoção } \\
\text { de fragmentos de rocha e } \\
\text { coberturas intemperizadas }\end{array}$ \\
\hline
\end{tabular}

$\mathrm{Na}$ Antártica, durante os curtos verões, colônias de pinguins com milhares de indivíduos incorporam à matriz mineral significativas quantidades de guano, juntamente à urina, pena, casca de ovos, conchas, restos animais e vegetais, receita esta que dá origem aos chamados solos ornitogênicos (TATUR e MYRCHA, 1993; MICHEL, 2005), cuja gênese está fundamentalmente vinculada aos resíduos que as aves em concentração ejetam na superfície. No Ártico, Butler (1995) chama a atenção a respeito do fradinho ou papagaio do mar (Fratercula arctica), ave colonial do Atlântico Norte que escava tocas em terrenos pronunciadamente íngremes que podem formar redes, e cuja escavação afeta as raízes da vegetação herbácea, que dessa forma seca durante o verão, promovendo assim o transporte eólico das coberturas superficiais.

Embora muitas aves escavem, ainda que na maioria das vezes muito pontualmente no espaço, o efeito do pisoteio não é contundente nesta classe, já que o número de aves de chão de grande porte

$\begin{array}{llllll}\text { Caminhos de Geografia } \quad \text { Uberlândia } & \text { v. 20, n. } 72 & \text { Dez/2019 } & \text { p. 275-293 Página } 281\end{array}$


é bastante restrito, se resumindo, basicamente, às aves ratitas atualmente distribuídas em porções fissionadas do Gondwana. Ademais, as ações escavadoras estão quase sempre vinculadas à construção de ninhos e à procura de alimento, esta última exercida por aves que predam invertebrados endopedônicos. Alguns ninhos podem se projetar em câmaras de alguns metros de comprimento, como as escavadas pela pardela do Pacífico (Puffinus pacificus) (BUTLER, 1995); embora também possa nidificar em fendas existentes em afloramentos rochosos, a escavação costuma ser tática para as paisagens abertas e desprotegidas que caracteriza muitas áreas litorâneas.

Ainda que as aves possam exercer ações geomórficas, as atividades que implicam em interações com as coberturas superficiais e com a vegetação suportada são bem mais sutis na classe das aves, bem como suas implicações nos processos de superfície. Entre os mamíferos, por outro lado, esta importância se amplifica sobremaneira, o que fica explícito no quadro 3.

Quadro 3 - Fatos geomórficos produzidos por mamíferos.

\begin{tabular}{|c|c|c|c|c|c|}
\hline AÇÃO & ESCALA & MANIFESTAÇÃO & $\begin{array}{l}\text { EXPRESSÃO } \\
\text { ESPACIAL }\end{array}$ & AGENTES & FATOS GEOMÓRFICOS \\
\hline $\begin{array}{l}\text { Procura por } \\
\text { alimento }\end{array}$ & $\begin{array}{l}\text { Local } \quad a \\
\text { regional }\end{array}$ & Superficial & $\begin{array}{l}\text { Pontual, linear } \\
\text { e areolar }\end{array}$ & Vários & $\begin{array}{lr}\text { Geração de } & \text { buracos, } \\
\text { depressões, } & \\
\text { remobilização } & \text { de } \\
\text { sedimentos } & \text { com } \\
\text { interferências } & \text { nos } \\
\text { processos erosivos e } \\
\text { sedimentares }\end{array}$ \\
\hline Pisoteio & $\begin{array}{l}\text { Local a } \quad a \\
\text { suprarregional }\end{array}$ & Superficial & $\begin{array}{l}\text { Pontual, linear } \\
\text { e areolar }\end{array}$ & $\begin{array}{l}\text { Vários, } \\
\text { sobretudo mega } \\
\text { herbívoros } \\
\text { formadores de } \\
\text { manadas }\end{array}$ & $\begin{array}{l}\text { Formação de sulcos ou } \\
\text { terracetes que favorecem } \\
\text { os processos erosivos }\end{array}$ \\
\hline Chafurdação & Local & Superficial & Pontual & Vários & $\begin{array}{l}\text { Remobilizações pontuais, } \\
\text { podendo formar } \\
\text { pequenos montes } \\
\text { depressões }\end{array}$ \\
\hline Geofagia & Local & $\begin{array}{l}\text { Superficial a } \\
\text { subsuperficial }\end{array}$ & Pontual & $\begin{array}{l}\text { Mamíferos } \\
\text { herbívoros, } \\
\text { notadamente } \\
\text { ungulados, } \\
\text { elefantes } \\
\text { primatas }\end{array}$ & $\begin{array}{l}\text { Remobilização de } \\
\text { material, podendo } \\
\text { acarretar a remoção da } \\
\text { cobertura vegetal e } \\
\text { desenvolvimento de } \\
\text { pequenos focos erosivos }\end{array}$ \\
\hline Escavação & Local & $\begin{array}{ll}\text { Superficial } & \text { a } \\
\text { subsuperficial } & \end{array}$ & Pontual & Vários & $\begin{array}{l}\text { Remobilização } \\
\text { material, geração de } \\
\text { buracos e depressões } \\
\text { com influência nos } \\
\text { processos erosivos e } \\
\text { sedimentares. }\end{array}$ \\
\hline $\begin{array}{l}\text { Barramento } \\
\text { de cursos } \\
\text { d'água }\end{array}$ & $\begin{array}{l}\text { Local } \\
\text { regional }\end{array}$ & Subaquosa & $\begin{array}{l}\text { Linear } \\
\text { areolar }\end{array}$ & Castor fiber & $\begin{array}{l}\text { Alteração nos processos } \\
\text { hidrodinâmicos com a } \\
\text { formação de níveis de } \\
\text { base locais } \\
\text { interferências associadas } \\
\text { nos processos erosivos e } \\
\text { sedimentares }\end{array}$ \\
\hline
\end{tabular}

A classe dos mamíferos é a que apresenta maior potencial geomórfico, em função de fatores relacionados aos hábitos, ao porte, aos efeitos de grupo e à índole eminentemente terrestre de

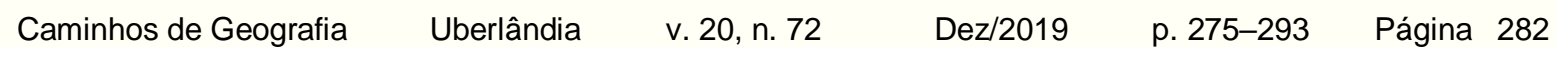


grande parte desse grupo. São os mamíferos terrestres, que habitam o chão, aqueles que respondem mais contundentemente ao desenvolvimento de formas e processos e que assumem maior valor na composição da paisagem, sendo o papel dos mamíferos arborícolas e aquáticos bem mais comedido.

A análise da literatura citada ao longo do artigo e as observações em campo apontam que o espectro mais geral das ações geomórficas de mamíferos remete às grandezas escalares locais, tal como acontece com aves e repteis. Agrupamentos de grandes animais em atos de chafurdação e dessedentação interferem de fato nos processos erosivos, afetando a coesão dos horizontes superficiais dos solos e influenciando na erosão marginal ao longo dos rios e demais hidrotopos, ambientes nos quais a concentração de grandes animais é recorrente. Esses efeitos processados fundamentalmente nos domínios superficiais podem ser mais francamente visualizados na fácies, unidade geossistêmica formada a partir de biocenoses elementares; nessas integridades espaciais as ações geomórficas da fauna ficam mais bem configuradas. As micromorfologias associadas às ações relacionadas à chafurdação e pisoteio para dessedentação costumam ficar registradas ao longo das fácies físico-geográficas pelas quais o animal transita e influencia nos fluxos de matéria e energia: o nexo geomorfológico expresso em buracos, tocas, terracetes, revolvimentos, rompimento de diques e depósitos correlatos, entre outros, se estabelece em escala de detalhe. No entanto, é bem verdade que tais padrões podem se repetir em mais de uma fácies, uma vez que muitos animais exploram diferentes habitats e ecossistemas, firmando interações que transpõem escalas predefinidas.

Existem casos, a propósito, que a ação geomórfica da mastofauna se consubstancia em grandes áreas, integralizáveis em grandezas regionais ou mesmo suprarregionais. É o caso de grandes manadas migratórias de mega herbívoros, como as renas e caribus (gênero Rangifer) que transumam entre a tundra e as latitudes mais baixas das florestas gimnospérmicas boreais e dos bosques caducifólios ao ritmo dos ciclos sazonais, os antilocapras (Antilocapra americana) das estepes norteamericanas e os gnus (Connochaetes taurinus e $C$. gnous) das savanas africanas, cujos bandos exageradamente numerosos também se deslocam movidos pela estacionalidade bem marcada nestas faixas latitudinais em busca de pastagens mais robustas e oferta de água. Quando empreendem a travessia de rios exercem um pisoteio massivo com implicações explícitas na erosão marginal. Estabelece-se um ritmo de ações geomórficas estreitamente relacionado às sucessões dos diferentes estados dinâmicos dos geossistemas, e que controlam a atividade faunística onde as variações anuais são pronunciadas.

Em contraste, a fauna domesticada, muito embora tenha potencial para exercer efeitos geomórficos expressivos, normalmente tais efeitos não obedecem ao ritmo da sazonalidade que orquestra a atividade anual da fauna silvestre. Os rebanhos bovinos criados influenciam sobremaneira na dinâmica das vertentes em função do pisoteio recorrente, sobretudo em contextos de pecuária intensiva, o que se dá indiferentemente a estes ritmos. Nos terrenos cristalinos do domínio tropical atlântico, onde o relevo é significativamente declivoso e dissecado, as microformas lineares vinculadas ao pisoteio são deveras marcantes ao longo das encostas, se manifestando pelas fácies de pastagens e coalescendo em diferentes grupos de fácies, chegando a assumir expressão regional.

\section{AÇÕES GEOMÓRFICAS DE MAMMALIA}

Muito embora algumas ações geomórficas levadas a efeito por mamíferos ocorram em várias ordens e famílias, existem ações francamente características de táxons específicos. A respeito da integridade taxonômica, os avanços nos estudos filogenéticos têm estimulado novas propostas na organização das ordens e famílias da classe Mammalia, com proposições que chegam a estabelecer cerca de vinte e duas ordens viventes, a exemplo daquela apresentada por Bergqvist et al. (2000). Para os objetivos da presente comunicação foi considerada a classificação mais sucinta e tradicional de Simpson (1945), ainda muito mencionada pela sua boa precisão nas divisões mais básicas, conservando as dezoito ordens mais consensuais e atendendo adequadamente a uma discussão que não perpassa o mérito filogenético: Monotremata, Marsupialia, Insectivora, Dermoptera, Chiroptera, Primates, Edentata (Xenarthra), Pholidota, Lagomorpha, Rodentia, Cetacea, Carnivora, Tubulidentata, Proboscidae, Hyracoidae, Sirenia, Perissodactyla, Artiodactyla.

Cabe pontuar que algumas ordens possuem todo o seu conjunto de espécies formado por organismos que efetivamente não descem ao chão, salvo em circunstâncias especiais, enquanto outras contam com representantes viventes cujos hábitos são exclusivamente aquáticos. São as

$\begin{array}{llllll}\text { Caminhos de Geografia } & \text { Uberlândia } & \text { v. 20, n. } 72 & \text { Dez/2019 } & \text { p. 275-293 } & \text { Página } 283\end{array}$


ordens Chiroptera, que congrega as variadas espécies de morcegos (a mais numerosa do biorreino Neotropical), Dermoptera (colugos e esquilos-voadores das florestas tropicais úmidas asiáticas), e a vasta maioria dos primatas. Ainda, as ordens Cetacea e Sirenia congregam animais eminentemente aquáticos, a primeira com a vasta maioria dos representantes viventes marinhos, e a segunda reunindo poucos peixes-boi, manatis e dugongos de ambientes dulcícolas ou de mar raso em porções intertropicais da América e Ásia. Estas ordens, em função da natureza de seus hábitos e nichos, não apresentam significância zoogeomorfológica, ainda que algumas exceções sejam fato. Por exemplo, cetáceos marinhos como grandes baleias, ao encalharem nas praias, podem promover a retenção em suas ossadas de sedimentos eolicamente transportados, acarretando a formação de dunas a partir de uma barreira orgânica funcional, conforme documentado por Rambo (1956) na porção meridional do litoral brasileiro.

No contexto biótico-evolutivo atual, a ordem Monotremata é a única pertencente à subclasse Prototheria, e congrega apenas os ornitorrincos (Ornithorhynchidae anatinus) e equidnas (Tachyglossidae) viventes na Austrália e na Nova Guiné, cujas histórias biogeográficas estão diretamente ligadas ao isolamento da Placa Australiana ainda no Eoceno, com a ruptura da ligação com a Placa da Antártica e consequente interrupção de fluxos gênicos com o Gondwana Ocidental (ZUNINO e ZULLINI, 2003). Os ornitorrincos, ocorrentes no leste da Austrália e Tasmânia, apesar de seus hábitos aquáticos, são eficientes escavadores, exercendo ações geomórficas nas margens de rios voltadas para a construção de alongadas tocas e para a captura de invertebrados que partilham de sua dieta. As equidnas, diferentemente dos ornitorrincos, são mamíferos de hábitos terrestres; porém, tal como seus aparentados, são eficientes construtoras de tocas por escavação no substrato. Sobre isso, Mitchell (1988) destaca seus efeitos geomórficos derivados dos processos de escavação vertical na superfície do solo ou diretamente nos termiteiros para a alimentação.

Além dos sui generis Monotrematas, os marsupiais figuram como um grupo mais diversificado na Oceania, mas também ocorrem na América do Sul acessoriamente à mastofauna placentária, onde são representados pelos didelmorfídeos (gambás e cuícas). Embora algumas classificações enquadrem o referido táxon como uma Supercoorte com várias subdivisões, aqui serão tratados como um conjunto geral da Infraclasse Metatheria (sensu SIMPSON, 1945). Nesse grupo, uma espécie bastante conhecida é o vombate (Vombatus ursinus) do sul da Austrália e Tasmânia, um dos mais eficientes escavadores entre os Marsupialia, capazes de construir com suas patas dianteiras galerias complexas e ramificadas que chegam a atingir 30 metros de comprimento, cruciais para proteção contra predadores naturais, como o diabo-da-tasmânia (Sarcophilus arrisi). Além dos vombates, processos de bioturbação também são levados a efeito por algumas espécies de canguru como Macropus major (BUTLER, 1995).

Mamíferos placentários mais primitivos como a ordem Insectivora contam com espécies viventes de pequeno porte, mas que trabalham contundentemente as coberturas superficiais. Os musaranhos eurasiáticos (família Soricidae) são notáveis construtores de galerias, onde nidificam e passam a maior parte do tempo. Solenodontes (família Solenodontidae) das ilhas de Cuba e Haiti/República Dominicana também escavam permanentemente em investida contra invertebrados que habitam as camadas superficiais e subsuperficiais do solo. Por último, são as toupeiras (família Talpidae) que congregam as espécies mais conhecidas da ordem em tela, e aquela que mais exerce retrabalhamento de coberturas de alteração, resultado de sua vida exclusivamente subterrânea, suportada por galerias mais complexas, com câmaras internas e várias saídas, e que são o seu território de locomoção, descanso, nidificação e alimentação (REICHMAN e SMITH, 1990; GAMBARYAN et al. 2002).

A ordem Insectivora mostra de forma contundente como mesmo mamíferos de pequeno porte tem potencial para se inscrever explicitamente nos sistemas geomorfológicos com os quais se relacionam, gerando formas e influenciando nos processos. Soma-se a esta categoria dimensional a ordem Rodentia, formada (salvo exceções) eminentemente por animais nanicos, mas que congrega

$\begin{array}{lllll}\text { Caminhos de Geografia } & \text { Uberlândia } & \text { v. 20, n. } 72 & \text { Dez/2019 } & \text { p. 275-293 Página } 284\end{array}$


espécies que exercem papel zoogeomorfológico efetivo. Seguramente, a ação geomórfica mais conhecida é aquela perpetrada pelo castor, representado nas espécies Castor fiber e Castor canadensis da Eurásia e América do Norte, respectivamente, e que é expressa pelos represamentos de cursos d'água a partir do corte, transporte e acomodação de material lenhoso para a construção de diques, criando níveis de base locais com reorganizações nos processos erosivos e deposicionais fluvais. Além do Homem, é o mamífero com maior capacidade de interferências nos processos geomorfológicos. Rossel et al. (2005) frisam que as espécies do gênero Castor exercem interferências geomorfológicas no contexto da própria paisagem, alterando os processos hidrodinâmicos, criando novos habitats e influenciando as sucessões ecológicas em função do corte de árvores que empreendem com os dentes incisivos. Asseveram ainda que as transformações e impactos variam conforme a localização geográfica, o tipo de relevo e as categorias de habitats existentes, assumindo grande potencial para o planejamento da paisagem e seu manejo. Normalmente, os impactos têm sido negativos nas localidades onde houve reintrodução compensatória à sobre-exploração que a espécie sofreu durante o século vinte.

Butler e Malanson (2005) diferenciam os efeitos geomórficos exercidos por castores durante a construção das represas daqueles que se desdobram com o desmantelamento das mesmas após algumas décadas de habitação. De acordo com os autores citados, a construção dos abrigos, levada a efeito pelo represamento de canais fluviais, provoca a acumulação de sedimentos, a redução da velocidade das correntes e a reconfiguração da paisagem com o aumento da área das zonas úmidas além dos canais definidos linearmente, com influências em larga escala. A maciça estocagem sedimentar, dada por materiais finos e detríticos, pode implicar no aparecimento de ilhas fluviais, com profunda alteração nos estilos fluviais e na natureza de sua carga de fundo. Os autores asseveram ainda que a falência dos diques, muitas vezes ligada ao declínio populacional dos castores em algumas regiões da América do Norte e Europa, faz com que quantidades significativas de água represada sejam redefinidas em fluxo concentrado de canal, acarretando perda da diversidade e produtividade da vegetação ripária, enquanto os sedimentos e nutrientes armazenados são lançados no sistema, comprometendo a qualidade hídrica a jusante, aumentando a carga de fundo dos canais fluviais e intensificando a erosão marginal.

A ordem Rodentia também é representada por outros organismos de interesse zoogeomorfológico, normalmente de hábitos escavadores. Em ambientes de deserto e pradaria, Davidson e Lighfoot (2008) estudaram os efeitos da ação conjunta exercida por ratos-canguru (Dipodomys spectabilis) e cães-da-pradaria (Cynomys gunnisoni), constatando que a ocorrência agregada das duas espécies engendra maiores distúrbios no solo, provê uma maior incorporação de matéria orgânica no sistema em função do material fecal e estimula a atividade de outros animais, repercutindo ainda no desenvolvimento de uma maior riqueza vegetal, aumentando os tipos de habitat existentes e a heterogeneidade da paisagem como um todo.

No Brasil as menções são escassas e estudos específicos praticamente inexistem para esta ordem. No entanto, encontramos várias evidências de processos erosivos vinculados à capivara (Hydrochoerus hydrochaeris), praticamente onipresente na região neotropical. Felix (2012) discutiu o impacto exercido pelo pastoreio dessa espécie em áreas agrícolas, bem como a tendência de a mesma acessar culturas e pastos plantados com Brachiaria pelos corpos d'água. De médio porte (é a maior espécie da ordem Rodentia) e com populações numerosas, exercem pastejo significativo em terraços, planícies fluviais, diques marginais e áreas adjacentes, expondo os depósitos com a remoção da vegetação, conforme aponta os registros da figura 3. Tais evidências ocorrem preferencialmente no médio e baixo curso de canais fluviais, onde os vales encontram-se mais evoluídos lateralmente e as planícies mais desenvolvidas, e se definem na exposição e remobilização de coberturas aluviais e alúvio-coluviais com possibilidade de formação de focos erosivos de alguns metros a algumas dezenas de metros, vinculados ao rebaixamento e à retirada da vegetação que os roedores impõem. A relação entre essas formas e processos com $H$. hydrochaeris pode ser atestada pela presença recorrente dos animais e por vestígios na forma de detritos orgânicos (figura 3C).

$\begin{array}{lllll}\text { Caminhos de Geografia } & \text { Uberlândia } & \text { v. 20, n. } 72 & \text { Dez/2019 } & \text { p. 275-293 Página } 285\end{array}$


Figura 3 - Focos erosivos associados à ação geomórfica de Hydrochoerus hydrochaeris, com exposição e remobilização de sedimentos inconsolidados: A) Baixo curso do rio São Pedro (Baependi, MG); B) Médio curso do rio Verde (Conceição do rio Verde, MG); C) Médio curso do rio Verde (Três Corações, MG).

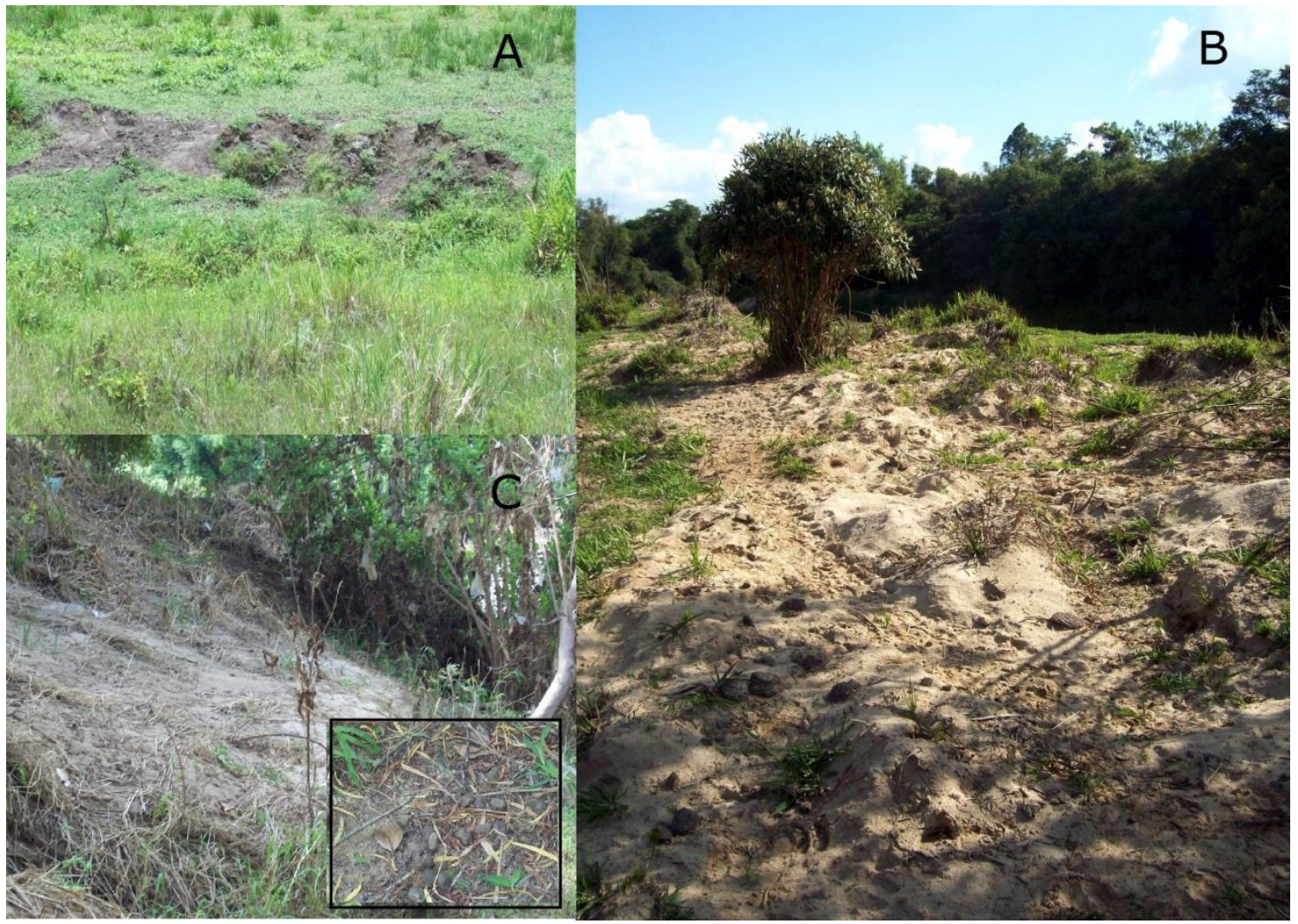

Indubitavelmente, os mamíferos Xenarthra (Pilosa), em função dos hábitos escavadores de algumas espécies, também devem ser colocados em lume nas discussões focadas nas relações entre a fauna e os sistemas geomorfológicos. No âmbito desse agrupamento assume protagonismo como agente geomórfico a família Dasypodidae (Cingulata), que abarca 21 espécies de tatus, onze delas ocorrentes na fauna brasileira (MEDRI et al. 2006) em ambientes florestais e de cerrado. A principal ação do referido táxon é a escavação, com diferentes padrões de tocas em altura, largura e comprimento variando conforme a espécie (CARTER e ENCARNAÇÃO, 1983). Para o tatu peba (Euphractus sexcinctus) em específico, (MEDRI, 2008) encontrou valores médios de largura de 19,4 $\mathrm{cm}$ e altura média de $15,5 \mathrm{~cm}$, o que implica em geração de microrrelevos e remobilização das coberturas superficiais retiradas durante a escavação, que ficam assim mais susceptíveis ao transporte pelo escoamento superficial. As demais famílias de Xenartha modernos não assumem significância geomórfica. Entre os Mirmecophagidae terrestres, apenas o tamanduá-bandeira (Myrmecophaga tridactyla) tem maior porte. Quanto às preguiças (Brasypodidae), embora os colossais megatérios terrestres do Pleistoceno fossem excelentes escavadores que legaram imensas cavidades aos sistemas geomorfológicos com os quais interagiam (BUCHMANN et al. 2009), os representantes atuais são essencialmente arborícolas.

Embora endêmicos da região Neotropical, os Xenartha da ordem Edentata (Cingulata) possuem um equivalente ecológico no continente africano que é o aardvark (Orycteropus afer), único representante da ordem Tubulidentata, que também se alimenta de formigas e térmitas, exercendo agressiva escavação nos termiteiros e provocando, consequentemente, a desestabilização das coberturas superficiais e provendo material sólido incoeso para os fluxos superficiais (BUTLER, 1995). Na mesma linha se estabelecem os pangolins africanos e da Ásia tropical (ordem Pholidota), adaptativamente convergentes aos tamanduás neotropicais, com espécies majoritariamente

$\begin{array}{llllll}\text { Caminhos de Geografia } & \text { Uberlândia } & \text { v. 20, n. } 72 & \text { Dez/2019 } & \text { p. 275-293 } & \text { Página } 286\end{array}$


terrestres e outras de hábitos fundamentalmente arborícolas, tal como ocorre com os Myrmecophagidae que habitam os neotrópicos.

Mamíferos de tamanho mais avantajado podem exercer trabalho geomórfico significativo. Um exemplo que tem sido recorrentemente observado no contexto brasileiro se refere ao javali (Sus scrofa), artiodáctilo de porte médio capaz de remobilizar quantidades significativas de material em superfície. Essa espécie exótica alcançou ampla distribuição, avolumando os efeitos engendrados pelos porcos selvagens nativos (Taiassuidae). Observações foram levadas a efeito em uma área de relevo montanhoso da Serra da Mantiqueira localizada no município de Itamonte (MG), região na qual Sus scrofa é recorrentemente avistado em grupos de tamanho variável. Nessa área de florestas ombrófilas mais contínuas podem ser aferidas dezenas de focos de material remobilizado de extensão métrica a decamétrica, vinculados à escavação, chafurdação e passagem dos grupos, que nas encostas declivosas desse relevo montanhoso formam pequenas trilhas lineares de pisoteio.

É fato que a expressão geomorfológica dos animais é mais latente no âmbito da megafauna, fundamentalmente os mega herbívoros terrestres. Nos grandes herbívoros, migratórios ou não, o protagonismo zoogeomorfológico normalmente reside nas espécies mais características que formam os bandos mais numerosos, e que coexiste com outras tantas espécies acessórias com significância geomórfica igualmente acessória, que pisoteiam ao mesmo estilo e em menor número. Exemplos ilustrativos podem ser extraídos do continente africano e, em menor medida, na grande região Holártica, porções do orbe onde a megafauna coevoluiu com o Homo sapiens, tendo assim subsistido em contraste à América do Sul, que teve praticamente toda sua megafauna terrestre exaurida após a chegada do Homem no Pleistoceno tardio (ainda que muitas espécies já viessem fenecendo há milênios pregressos à entrada humana). Assim, os numerosos agrupamentos de gnus (gênero Connochaetis) migram, pastam e dessedentam ao lado de zebras (gênero Equus), girafas (Giraffa camelopardalis) e alguns veados como a gazela-de-Thompson (Gazella thomsoni), todos pisoteadores efetivos. Na região Holártica também ocorrem grandes migrações como a das renas (gênero Rangifer), dos antilocapras (Antilocapra americana) e dos bisões (Bison bison) da América do Norte, que estão entre os maiores bovídeos selvagens (MARQUES NETO, 2018).

Grandes migrações sazonais são típicas de artiodáctilos, sobretudo cervídeos, e alguns perissodáctilos, como as zebras. Menos numerosa, porém digna de nota, a ordem Proboscidae tem no deslocamento das manadas de Loxodonta africana uma importante representação no que concerne à ação geomórfica do pisoteio, consorciada ao consumo de significativa massa vegetal, subtraída para a alimentação ou seviciada pela passagem dos paquidermes, o que exerce desdobramentos diretos no ritmo e dinâmica das sucessões ecológicas. Como característica, ao longo das principais rotas migratórias dos grandes herbívoros pertencentes às ordens discutidas, a vegetação é mais rarefeita e as coberturas superficiais mais expostas e incoesas em suas camadas e horizontes superficiais.

O movimento da fauna ao longo da paisagem está estreitamente relacionado à estrutura da mesma, que pode facilitar ou dificultar o deslocamento do organismo. Aqui estrutura da paisagem é entendida como o arranjo espacial de seus atributos componentes e as formas pelas quais são estabelecidas as relações de interdependência e reciprocidade (RODRIGUEZ et al. 2010). Forman e Godron (1986) apresentam reflexão interessante acerca desta questão, diferenciando os movimentos contínuos, cuja velocidade não é zerada por efeito de algum fator condicionante, e os movimentos saltatórios, interrompidos por tempos variáveis durante o deslocamento do organismo ou grupo de organismos entre duas ou mais localidades. Os movimentos contínuos são caracterizados por sua constância, sem acelerações ou desacelerações acentuadas e com poucas interrupções, o que é característico de paisagens dotadas de estrutura relativamente homogênea, sem grandes mudanças ou variações em sua composição geral, como os campos abertos das tundras que permitem as migrações das renas e caribus (gênero Rangifer) ou as estepes norte-americanas exploradas pelos antilocapras (Antilocapra americana); ainda, pelas savanas herbáceas com árvores esparsas da África migram os gnus (gênero Connochaetes) aos milhares, juntamente com outros mega herbívoros, exercendo massivo efeito de pisoteio; quando as manadas cruzam rios, assumem mérito na erosão das margens. No território brasileiro, embora a mastofauna atual não se organize em manadas, os campos cerrados em terrenos intermontanos do Brasil Central figuram como paisagens bastante aptas para deslocamentos mais longos.

$\begin{array}{llllll}\text { Caminhos de Geografia } \quad \text { Uberlândia } & \text { v. 20, n. } 72 & \text { Dez/2019 } & \text { p. 275-293 } & \text { Página } 287\end{array}$


Os movimentos saltatórios, por seu turno, são mais comuns em paisagens estruturalmente heterogêneas, ou seja, que apresentam significativas variações de relevo, hidrografia, vegetação e outros atributos em espaços relativamente restritos. Tal padrão de deslocamento tende a imprimir alterações mais significativas em comparação aos movimentos contínuos, uma vez que a prevalência dos animais em algum ponto resulta em mudanças na estrutura superficial da paisagem em função do tempo maior de pisoteio e escavações no solo, favoráveis para o desenvolvimento de processos erosivos. Por outro lado, a concentração de espécies pode favorecer a fertilização dos pontos de parada a partir de seus excrementos ou atividades de predação nas quais restos são abandonados, contribuindo com a reciclagem de nutrientes. Tais paradas, segundo Forman e Godron (1986) podem ser efêmeras e interromperem brevemente o movimento da espécie, e são designadas como paradas de descanso, pela qual a espécie se restaura e, em seguida, retoma a sua marcha. Os autores frisam ainda que algumas paradas são mais demoradas, e ocorrem quando a espécie chega a colonizar a área, se reproduzindo e crescendo e dali se expandindo. São as chamadas paradas trampolim, caracterizadas por uma maior prevalência dos grupos, que aproveitam os recursos da área por determinado período antes de retomarem o descolamento no espaço.

Nessas paradas é que os herbívoros das ordens Artiodactyla, Perissodactyla e Proboscidae exercem efeito geomórfico em caráter mais pontual e concentrado. Primeiro, tem-se o pisoteamento na superfície, que tende a ser adensado nos locais de descanso e dessedentação, onde normalmente grandes herbívoros se reúnem. No entorno desses ambientes são comuns ações de chafurdação, como levado a efeito por búfalos Syncerus caffer da África subsaariana e Bubalus bubalis da Ásia tropical, hipopótamos (Hippopotamus amphibius) e as cinco espécies de rinocerontes da África, Índia e Indonésia.

Entre os fatores elencados por Diamond (2014) que motivaram e possibilitaram a domesticação, três deles favoreceram sobremaneira animais que exercem pisoteio, quais sejam: (1) grande porte, fornecendo assim boas quantidades de alimento e servindo como tração; (2) hábitos alimentares herbívoros, o que garante um déficit energético aceitável por sua posição trófica inferior; (3) índole adequada à domesticação, característica comum em animais de manada que obedecem a uma liderança que encabeça o grupo. Animais com tais características figuram em fartos coletivos nos rebanhos manejados de bovinos, caprinos, equinos e bubalinos, fundamentalmente. Hall e Lamont (2003) registram os efeitos do pisoteio promovidos pelos iaques (Bos grunniens) nas vertentes do Himalaia tibetano expressos pela proliferação de terracetes; no Brasil, efeitos bioerosivos vinculados ao rebanho bovino foram divulgados por Thomaz e Dias (2009).

A fauna domesticada voltada para a criação em massa no Brasil é liderada, de longe, pelo rebanho bovino, sendo as demais espécies assaz acessórias a Bos taurus, criado no território brasileiro em diversas raças. Inequivocamente é a espécie que assumiu maior ubiquidade e presença nas espacialidades rurais brasileiras, e a que partilha de forma mais contundente na composição da paisagem. Caprinos, embora presentes em outras regiões, são mais copiosos no semiárido em função de sua plasticidade alimentar, adequada neste contexto morfoclimático onde as pastagens por vezes são muito rarefeitas. Quanto aos bubalinos, sua distribuição geográfica é ainda mais restrita, com o conhecido grupo asselvajado da Ilha de Marajó (AP) e algumas investidas criatórias pontuais mais recentes em outras regiões do país. Por exemplo, no município de Aiuruoca (sul de Minas Gerais) os búfalos são criados em planícies fluviais, onde remobilizam os sedimentos incoesos pelo pisoteio e chafurdação.

A maior densidade demográfica da megafauna domesticada no Brasil se estabelece no gado bovino, que exerce assim protagonismo zoogeomorfológico e influência expressiva nos processos erosivos. A relevância do gado nos processos de superfície, bem como a intensidade destes processos, depende de fatores como o número de indivíduos por unidade de área, tipo de solo, declividade do terreno e práticas de manejo, além das influências climáticas.

Sumarizando as ações geomórficas da fauna, em especial de mamíferos, além de seus efeitos diretos e indiretos, verifica-se também uma franca distinção dos fatos geomórficos associados aos animais em função do porte, clivando-se os mamíferos de pequeno a médio porte na categoria dos genuínos escavadores e aqueles de grande porte qualificados como pisoteadores (figura 4). Em geral, a escavação se integraliza em escala de detalhe, manifestando-se nas fácies, enquanto o pisoteio pode exercer influência desde níveis escalares locais até os geossistemas regionais.

\begin{tabular}{llllll}
\hline Caminhos de Geografia & Uberlândia & v. 20, n. 72 & Dez/2019 & p. 275-293 & Página 288
\end{tabular}


Figura 4 - Tipologias mastofaunísticas e tipos principais de ações geomórficas associadas.

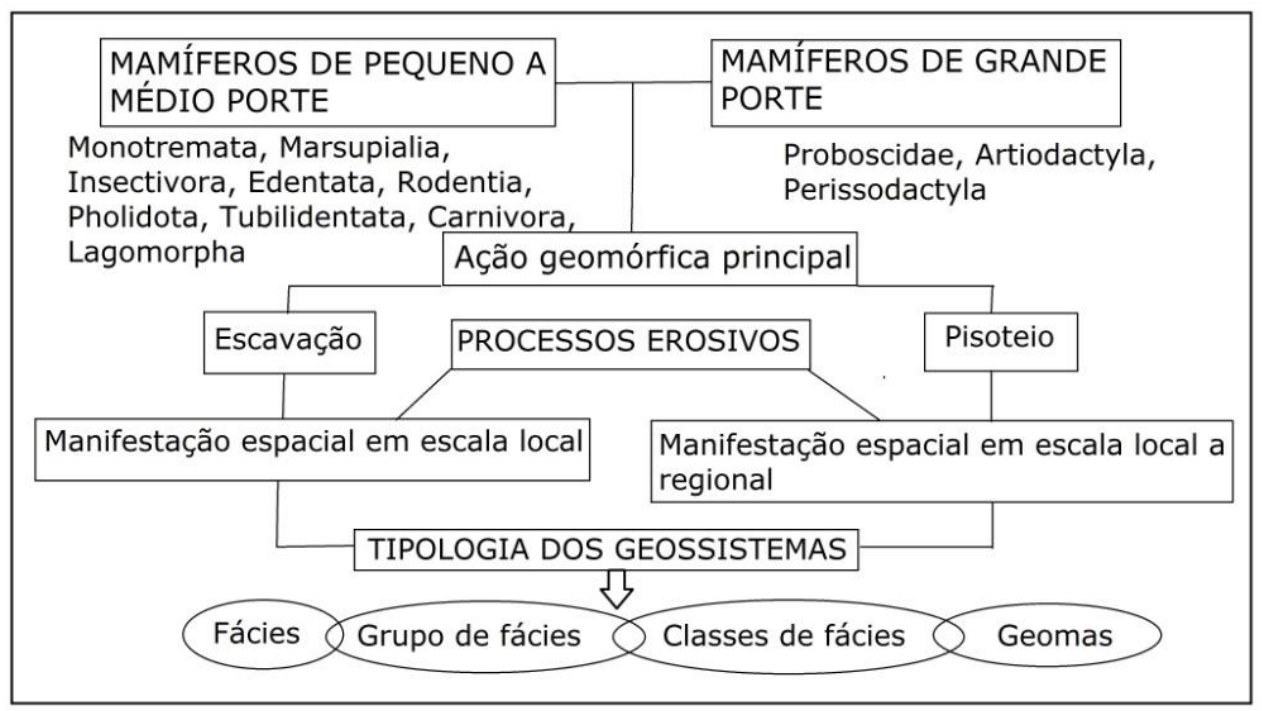

Pelo que a figura revela, animais não muito grandes possuem dimensão corpórea compatível com abrigos subterrâneos, e a megafauna remanescente não manteve escavadores de grande porte, salvo exceções, como alguns ursídeos. Em geral, seus efeitos geomórficos são localizados, salvaguarda casos específicos como o dos castores, já discutidos, cuja interferência pode afetar toda a paisagem, e não apenas fácies de manifestação espacial local. A escavação afeta fundamentalmente a subsuperfície, dissociando as sínteses dos minerais de argila e interferindo nas organizações estruturais do solo. Embora o registro do Quaternário e mesmo a crônica fóssil mais antiga revelem a existência de paleotocas, abertas ou preenchidas por sedimentos (crotovinas), como atestado por uma série de trabalhos (BUCHMANN et al. 2009; CARMO et al. 2011; RUCHKYS et al. 2014), normalmente estas estruturas não ficam preservadas. Tocas desmoronam com o tempo, alterando as formas de relevo e reorganizando os processos erosivos e deposicionais locais. $O$ caráter pequeno a médio da biota escavadora neotropical hodierna favorece essa relação direta entre a atividade geomórfica e as fácies físico-geográficas, discerníveis e integralizáveis em escala de detalhe (figura 5).

Figura 5 - Atividades geomórficas de escavação levadas a efeito por mamíferos neotropicais. A) Toca escavada por tatu-galinha (Dasypus novemcinctus) em Argissolo em área de campo herbáceo intermontano sobre gnaisses (Minduri, MG); B) Evidência de escavação e remobilização de Neossolo Litólico arenoso por lobo-guará (Chrysocyon brachyurus) em área de campo herbáceo altimontano sobre quartzito.

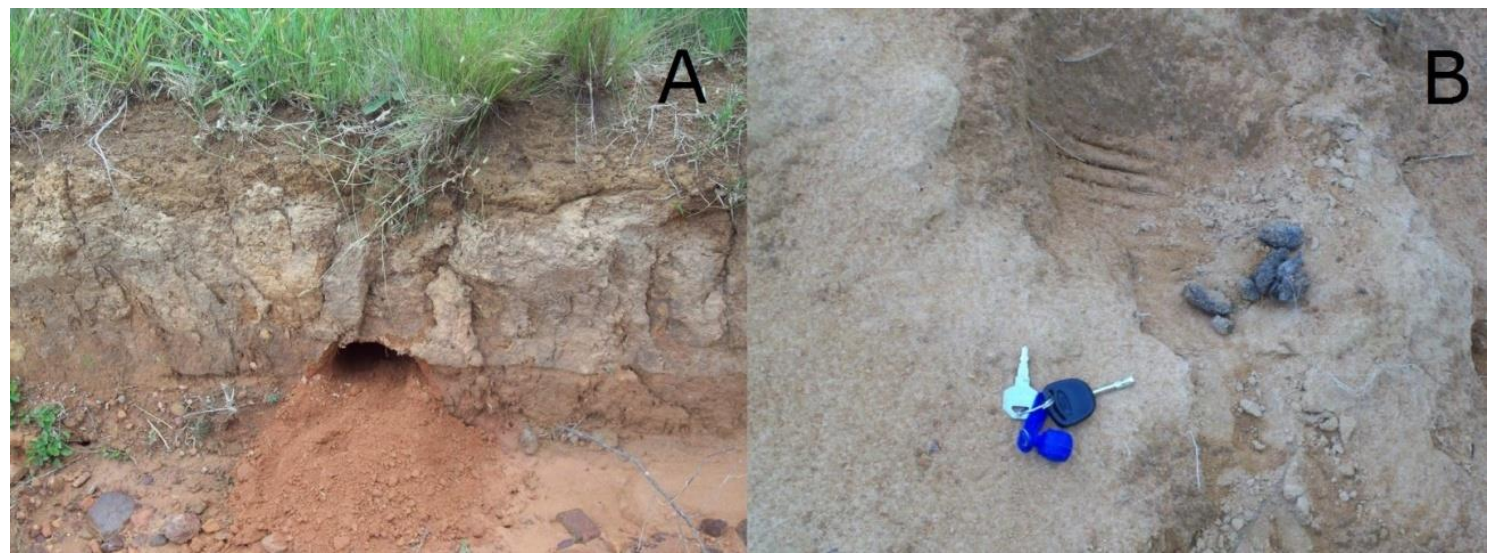
Caminhos de Geografia
Uberlândia
v. 20, n. 72
Dez/2019
p. $275-293$
Página 289 
Em conjunto, as ações de pisoteio e escavação tem potencial para fazer eclodir focos de erosão e intensificar processos erosivos em curso, remobilizando material sedimentar nas vertentes, planícies e diques marginais, exercendo erosão das margens e interferindo na carga sedimentar de canais e lagoas naturais de dessedentação. Pisoteio, escavação e outras forças direcionadas à estrutura superficial da paisagem modificam a morfologia das vertentes e desencadeiam processos erosivos. Estas e outras ações geomórficas que foram colocadas em discussão não têm sido suficientemente estudadas, nem quanto às suas modalidades, tampouco quanto aos táxons envolvidos, faltando assim um conhecimento mais sistemático e detalhado sobre o papel da fauna nos fluxos de matéria e energia vigentes no âmbito dos sistemas geomorfológicos tropicais. Embora, amiúde, a importância geomórfica dos animais seja lembrada, pesquisas sistemáticas no Brasil faltam tanto na Geomorfologia como na Biogeografia, com esforços pontuais e incipientes na tentativa de compreensão destas relações.

\section{CONCLUSÕES}

Animais são importantes agentes geomórficos, e o seu papel na dinâmica e evolução do relevo têm sido muito negligenciados, ou no mínimo relegado ao segundo plano nos estudos geomorfológicos. Ainda assim, a discussão aqui exposta constatou que algumas pesquisas estabelecidas nesse enfoque têm sido levadas a efeito, fundamentalmente em países de clima temperado, com contrastes sazonais muito fortes. No Brasil, tais abordagens são incipientes, e esta relevante interface entre a Geomorfologia e a Biogeografia não tem sido explorada. Por um lado, os estudos de cunho zoogeográfico padecem de letargia histórica no escopo da Geografia Física praticada no Brasil; a Geomorfologia, por seu turno, amplamente difundida e diversificada em território nacional, também não tem dado atenção a este tema. Dessa forma, o encaminhamento final da discussão comporta alguns pontos conclusivos.

(1) No contexto Neotropical a atividade geomórfica de grandes mamíferos tende a ser mais comedida - Decorre de uma megafauna restrita em porte e da biomassa vegetal dos corpos florestais, fazendo com que os efeitos indiretos vinculados ao consumo da vegetação não sejam tão relevantes nos processos de superfície vistos na escala da paisagem. No entanto, ampla literatura aponta que no interior das florestas tropicais úmidas impera uma intensa atividade de invertebrados e microrganismos que se enlaçam estreitamente à silvogênese e à estrutura interna dos corpos florestais;

(2) A isotermia favorece para que não haja grandes reorganizações sazonais da atividade faunística - Em contextos morfoclimáticos caracterizados por baixa amplitude térmica anual, a exemplo das florestas tropicais úmidas, atividades de escavação para hibernação e a migração de grandes herbívoros pastadores não é um fenômeno corrente;

(3) As principais ações geomórficas da fauna estão mais ligadas ao porte do que às ordens - É crível que atividades de escavação são dominantes em mamíferos de pequeno e médio porte, e o pisoteio em megamamíferos, fundamentalmente.

(4) No âmbito da fauna brasileira, os grupos mastofaunísticos mais relevantes enquanto agentes geomórficos são de médio porte - Figuram nesse rol fundamentalmente a família Dasypodidae (tatus escavadores), remanescentes terrestres da grande linhagem dos Xenartha do Pleistoceno; roedores e artiodáctilos taiassuídeos também exercem influência geomórfica digna de nota;

(5) Durante o Pleistoceno a atividade geomórfica de mamíferos deve ter sido mais expressiva no contexto neotropical - Ainda ao final do último estágio glacial, a crônica fóssil mostra que era conspícua a presença na América do Sul de grandes pastadores (equídeos, camelídeos, cervídeos extintos) e Xenartha agigantados (megatérios, gliptodontes), o que certamente realçava as ações de pisoteio e escavação em comparação ao quadro dinâmico atual;

(6) O manejo de espécies domesticadas, em alguma medida, reimplanta na paisagem ações geomórficas pretéritas - As referidas ações são estabelecidas no pisoteio, e também no consumo de vegetação nos casos de pastagens naturais, manifestando-se assim como importantes emergências nas espacialidades específicas das zonas rurais.

(7) A fauna partilha da composição dos geossistemas em caráter interescalar - 0 estudo da fauna segundo um enfoque zoogeomorfológico admite uma interpretação

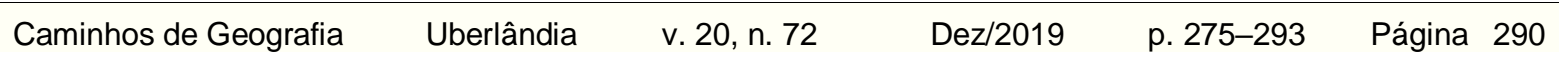


ancorada na abordagem sistêmica, uma vez que os animais se inscrevem de forma explícita na rede de interações que perfaz a estrutura e dinâmica dos geosssitemas, tendo expressão espacial e exercendo ações geomórficas que podem se manifestar das fácies às organizações espaciais regionais.

\section{REFERÊNCIAS}

ANTUNES, P. D.; FIGUEIREDO, L. H. A.; SILVA, J. F.; KONDO, M. K.; SANTOS NETO, J. A.; FIGUEIREDO, M. A. P. Caracterização físico-química de microrrelevo de montículos "murundus" na região de Janaúba no norte de Minas Gerais. Geonomos, v. 20, n. 1, p. 81-85, 2012. https://doi.org/10.18285/geonomos.v20i1.30

ARAÚJO NETO, M . D.; FURLEY, P. A. HARIDASAN, M.; JOHNSON, C. E. The murundus of the cerrado region of Central Brazil. Journal Tropical Ecology, v. 2, p. 17-35, 1986. https://doi.org/10.1017/S0266467400000559

BERGQVIST, L. P.; ABUHID,V. S.; GIUDICE, G. M. L. (2000) Mamíferos. In: CARVALHO, I. S. (Ed.) Paleontologia. Rio de Janeiro: Interciência, p. 595-623.

BUCHMANN, F. S.; LOPES, R. P.; CARON, F. Icnofósseis (paleotocas e crotovinas) atribuídos a mamíferos extintos no sudeste e sul do Brasil. Revista Brasileira de Paleontologia, v. 12, n. 3. p. 247-256, 2009. https://doi.org/10.4072/rbp.2009.3.07

BUCHMANN, F. S.; CARMO, F. F.; CARMO, F. F.; JACOBI, C. M.; FERREIRA, V. M. S.; FRANK, H. T. Paleotocas desenvolvidas em rochas ferríferas: importante registro da megafauna no norte de Minas Gerais. In: CARMO, F. F.; KAMINO, L. H. Y. Geossistemas ferruginosos do Brasil: áreas prioritárias para conservação da diversidade geológica e biológica, patrimônio cultural e serviços ambientais. Belo Horizonte: 3i Editora, 2015. 551p.

BUTLER, D. R. Zoogeomorphology: animals as geomorphic agents. Cambridge: Cambridge University Press, 1995. 211p. https://doi.org/10.1017/CBO9780511529900

; MALANSON, G. P. The geomorphic influences of beaver dams and failures of beaver dams. Geomorphology, v. 71, p. 48-60, 2005.

https://doi.org/10.1016/j.geomorph.2004.08.016

CAMARGO, J. C. G.; TROPPMAIR, H. A evolução da biogeografia no âmbito da ciência geográfica no Brasil. Geografia, Rio Claro, v. 27, n. 3, p. 133-155, 2002.

CARMO, F. F.; CARMO, F. F. BUCHMANN, F. S.; FRANK. H. T.; JACOBI, C. M. Primeiros registros de paleotocas desenvolvidas em formações ferríferas, Minas Gerais, Brasil. In: XXXI Congresso Brasileiro de Espeleologia. Anais... Ponta Grossa, PR, 2005. p. 531-540.

CARTER, T. S.; ENCARNAÇÃO, C. D. Characteristics and use of burrows by for species of armadillos in Brazil. Journal of Mammalogy, v. 64, n. 1, p. 103-108, 1983. https://doi.org/10.2307/1380755

CAVALCANTI, L. C. S. Da descrição de áreas à Teoria dos Geossistemas: uma abordagem epistemológica sobre sínteses naturalistas. 2013, 205p. Tese (Doutorado em Geografia), Universidade Federal de Pernambuco, Recife, 2013.

DAVIDSON, A. D.; LIGHFOOT, D. C. Burrowing rodents increase landscape heterogeneity in a desert grassland. Journal of Arid Environments, v. 72, p. 1133-1145, 2008.

https://doi.org/10.1016/j.jaridenv.2007.12.015

DIAMOND, J. Armas, germes e aço: os destinos das sociedades humanas. Rio de Janeiro: Editora Record, 2014. 472p.

FELIX, J. A. Comportamento alimentar e qualidade de carne de capivara (Hydrochoerus hydrochaeris, Linnaeus, 1766) de vida livre, em áreas agrícolas. Dissertação (mestrado em Zootecnia), Universidade Federal da Grande Dourados, Dourados, 2012. 81p.

FORMAN, R. T. T.; GODRON, M. Landscape ecology. New York: John Wiley \& Sons, 619p, 1986.

$\begin{array}{llllll}\text { Caminhos de Geografia } & \text { Uberlândia } & \text { v. 20, n. } 72 & \text { Dez/2019 } & \text { p. 275-293 } & \text { Página } 291\end{array}$


GAMBARYAN, P. P.; GASC, J. P.; RENOUS, S. Cinefluorographical study of the burrowing in the commom mole, Talpa europaea (Lipotyphla, Talpidae). Russian Journal of Theriology, v. 1, n. 2, p. 91-109, 2002. https://doi.org/10.15298/rusitheriol.01.2.03

HALL, K.; LAMONT, N. Zoogeomorphology in the Alpine: some observations on abiotic-biotic interactions. Geomorphology, v. 55, n. 1-4, p. 219-234, 2003. https://doi.org/10.1016/S0169$\underline{555 \times(03) 00141-7}$

ISACHENKO, A. G. Principles of landscape science and Physical Geography Regionalization. Melbourne, 1973. 311p.

MARQUES NETO, R. Zoogeografia do Brasil: a fauna, a paisagem e as organizações espaciais. Curitiba: CRV, 2018. 388p https://doi.org/10.24824/978854442302.8

MEDRI, I. M. Ecologia e história natural do tatu-peba, Euphractus sexcinctus (Linnaeus, 1758), no Pantanal da Nhecolândia, Mato Grosso do Sul. Tese (Doutorado em Ecologia), Universidade de Brasília. Brasília, 2008. 167p. https://doi.org/10.1896/020.010.0108

MEDRI, I. M.; MOURÃO, G.; RODRIGUES, F. H. G. (2006) Ordem Xenarthra. In: REIS, N. R.; PERACCHI, A. L.; PEDRO, W. A.; LIMA, I. P. (Eds.) Mamíferos do Brasil. Londrina: Nélio dos Reis: 71-99.

MICHEL, R. F. M. Solos criogênicos e ornitogênicos da área de entorno da Ponta Llano, Antártica Marítima. Tese (Doutorado em Solos e Nutrição de Plantas), Universidade Federal de Viçosa. Viçosa, 2005. 146p.

MIKLÓS, A. A. W. Biogênese do solo. Revista do Departamento de Geografia, v. especial, p. 190229, 2012. https://doi.org/10.7154/RDG.2012.0112.0011

MITCHELL, P. The influences of vegetation, animals and micro-organisms on soil processes. In: VILES, H. A. (ed.). Biogeomorphology. Blackwell: New York, 1988. p. 43-82.

PENTEADO-ORELLANA, M. M. Microrrelevos associados à térmitas do cerrado. Notícia Geomorfológica, v. 20, p. 61-72, 1980.

RAMBO, S. J. B. A fisionomia do Rio Grande do Sul. $2^{\circ}$ ed. Porto Alegre: Selbach \& Cia, 1956. 456p.

REICHMAN, O. J.; SMITH, S. C. (1990) Burrows and burrowing behaviors by mammals. In: GENOWAYS, H. H. Current Mammalogy. Plenun Press: New York and London: 197-244.

RESENDE, M.; CURI, N.; REZENDE, S. B.; CORRÊA, G. F. Pedologia: base para a distinção de ambientes. Lavras: Editora UFLA, 2007. 322p.

RODRIGUEZ, J. M. M.; SILVA, E. V.; CAVALCANTI, A. P. Geoecologia das paisagens: uma visão geossistêmica da análise ambiental. $3^{\circ}$ ed. Fortaleza: edições UFC, 222p, 2010.

ROSSEL, F.; BÓZSER, O.; COLLEN, P.; PARKER, H. Ecological impacts of beavers Castor fiber and Castor canadensis and their ability to modify ecosystems. Mammal review, v. 35, n. 3-4, p. 248-276, 2005. https://doi.org/10.1111/j.1365-2907.2005.00067.x

RUCHKYS, U. A.; BITTENCOURT, J. S.; BUCHMANN, F. S. C. A paleotoca da Serra do Gandarela e seu potencial como geossítio do Geoparque Quadrilátero Ferrífero, Minas Gerais. Cadernos de Geografia, v. 24, n. 42, p. 249-263, 2014. https://doi.org/10.5752/P.2318-2962.2014v24n42p249

SCHAEFER, C. E.; CÂNDIDO, H. G.; CORRÊA, G. R.; PEREIRA, A.; NUNES, J. A.; SOUZA, O. F.; MARINS, A.; FERNANDES FILHO, E.; KER, J. C. Solos desenvolvidos sobre canga ferruginosa no Brasil: uma revisão crítica e papel ecológico dos termiteiros. In: CARMO, F. F.; KAMINO, L. H. Y. Geossistemas ferruginosos do Brasil: áreas prioritárias para conservação da diversidade geológica e biológica, patrimônio cultural e serviços ambientais. Belo Horizonte: 3i Editora, 2015. 551p.

SIMPSON, G. G. The principles of classification and a classification of mammals. Bulletin of the American Museum of Natural History, v. 85, p. 1-350, 1945.

SOCHAVA, V. B. Geography and ecology. Soviet Geography: review and translation. New York, v. 12, n. 5, p. 277-293, 1971. https://doi.org/10.1080/00385417.1971.10770247

O Estudo dos Geossistemas. Métodos em Questão. n 16., 1977.

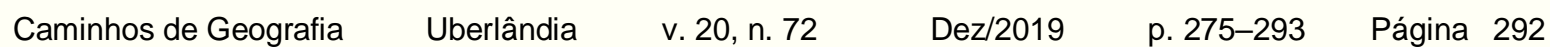


Por uma Teoria de Classificação dos Geossistemas da Vida Terrestre. Biogeografia. São Paulo. n. 14, 1978.

TATUR, A.; MYRCHA, A. (1993) Ornithogenic soils. In: RAKUSA-SUSZCZEWSKI, S. (ed.) The Antartic Cosastal Ecosystem of Admiralty Bay. Polish Academy of Sciences: p. 161-165.

THOMAZ, E. L.; DIAS, W. A. Bioerosão - evolução do rebanho bovino brasileiro e implicações nos processos geomorfológicos. Revista Brasileira de Geomorfologia, v. 10, n. 2, p. 3-11, 2009. https://doi.org/10.20502/rbg.v10i2.125

ZUNINO, M; ZULLINI, A. Biogeografía: la dimensión espacial de la evolución. MÉXICO, D. F: Fondo de Cultura Económica, 2003. 359p.

Recebido em: 04/11/2018

Aceito para publicação em: 26/11/2019 